\title{
AGE AND GROWTH OF CALLIONYMUS LYRA L.
}

\author{
By Hsiao-Wei Chang \\ British Council Scholar and Ray Lankester Investigator \\ (Academia Sinica, Shanghai)
}

(Plate I and Text-figs. I-4)

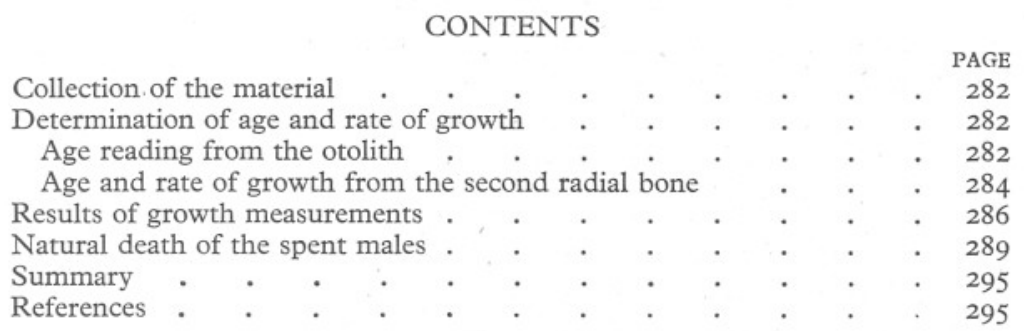

The Common Dragonet, Callionymus lyra L., is one of the commonest fishes in the Plymouth area, and is widely distributed in European seas. Recent reports indicate that it occurs also off the coast of West Africa (Fowler, I936; Poll, 1949). This fish, like others of the genus, attracts attention because, although it has very little economic importance, it is strikingly coloured and the sexes are markedly different. Work has been done on the breeding by Holt (I897, I898), and by Holt \& Scott (I898); on ova and larvae by M'Intosh (I885), M'Intosh \& Prince (I889), Cunningham (I89I), Holt (I897), Ehrenbaum (1905-9), Fage (1918), Mielck (1925), Duncker, Ehrenbaum, Kyle, Mohr \& Schnakenbeck (1929); on seasonal abundance and distribution of post-larvae off Plymouth by Russell (1930-47) and Corbin (1948); and on the skeleton by Günther (I86I) and Ford (1937). The mature males are provided with remarkable secondary sexual characters both in coloration and in relative lengths of snout and of median fins, which render them so different from the females that they were originally regarded as different species and known as the Gemmeous Dragonet (male C. lyra L.) and the Sordid Dragonet (female C. lyra L. =C. dracunculus L.) respectively (Donovan, I808; Yarrell, I859; Couch, I863). The sexual dimorphism and seasonal variation of this species has been much studied by Holt (I898), Smitt (1892-95), Gallien (1934), Letaconnoux (1949) and Desbrosses (1949). Very little information has so far been provided about its age and growth, with which the present paper deals.

I am greatly indebted to Mr F. S. Russell, F.R.S., for suggesting this investigation to me; and to $\mathrm{Mr} \mathrm{G}$. A. Steven for advice and assistance while 
it was being carried out and for much help in the preparation of the manuscript; to Mr G. M. Spooner for statistical advice and assistance; to Dr T. J. Hart and Mr M. D. Menon for help in the use of the radial bone for age determination; and to $\mathrm{Dr}$ J. S. Alexandrowicz who took the photographs. I have also the greatest pleasure in recording my indebtedness to the British Council and to the Trustees of the Ray Lankester fund for financial assistance without which this work could not have been done.

\section{COllection of the MAterial}

All the specimens for this study were trawled off Plymouth by the research vessels Sula and Sabella and the research launch Gammarus during a period of I8 months, from December 1948 till May I950. Some young fish were obtained also in the autumn and winter of 1950. During the first few months of the investigation the specimens were caught mainly by ordinary otter-trawl and partly by small beam-trawl (shrimp-netting), and very few fish below $50 \mathrm{~mm}$. in length were collected. In order to obtain more young fish an Agassiz trawl with fine mesh and an otter-trawl with small mesh cover to the cod-end were also used later on. Nevertheless, the difficulty of obtaining sufficient numbers of young fish had not been solved. The total number of fish thus collected for this work amounts to over 4000 specimens varying from 20 to $240 \mathrm{~mm}$. in standard length, including both sexes.

Monthly samples were taken and treated separately. Each fish was labelled and measured to the nearest millimetre, from the tip of the snout to the tip of the distal end of the longest caudal ray (total length) and from the tip of the snout to the distal end of the caudal hypural (standard length or body length). Then they were weighed to the nearest gram in a Salter spring balance and sexed. The large males above $80 \mathrm{~mm}$. can easily be sorted out by means of the male secondary sexual characters, but those below that length were all confirmed by examining the gonads. Before preservation in formalin for other purposes, an otolith or the complete right pectoral girdle, or both of them, were removed and kept in small numbered envelopes for later study.

\section{Determination of Age and Rate OF GROWTH}

There are no published data on the age and growth of this fish. Dr P. Desbrosses told me, in October 1949, that he had successfully used the otoliths to determine the age of $C$. lyra, but his results have not yet been published.

\section{Age Reading from the Otolith}

As C. lyra is devoid of scales, the otoliths were at first used for the age determination. The otolith belongs to the labrid type; its outer side is flat, inner side convex, dorsal rim domed and regular, and ventral rim curved (Frost, 1928). It is quite thin, and the number of rings on the fresh otoliths 
can easily be read under a binocular dissecting microscope against a dark background. If the otolith has been dried it must be immersed in water before examination, otherwise the rings cannot be distinguished easily. The central area of the otolith is opaque, with alternating rings of transparent (slow growth zone) and opaque (rapid growth zone) material. Altogether, 2407 otoliths taken

Table I. Percentage of Fish with Slow or Rapid Growth Zones at the Margin of the Otolith and of the Second Radial Bone

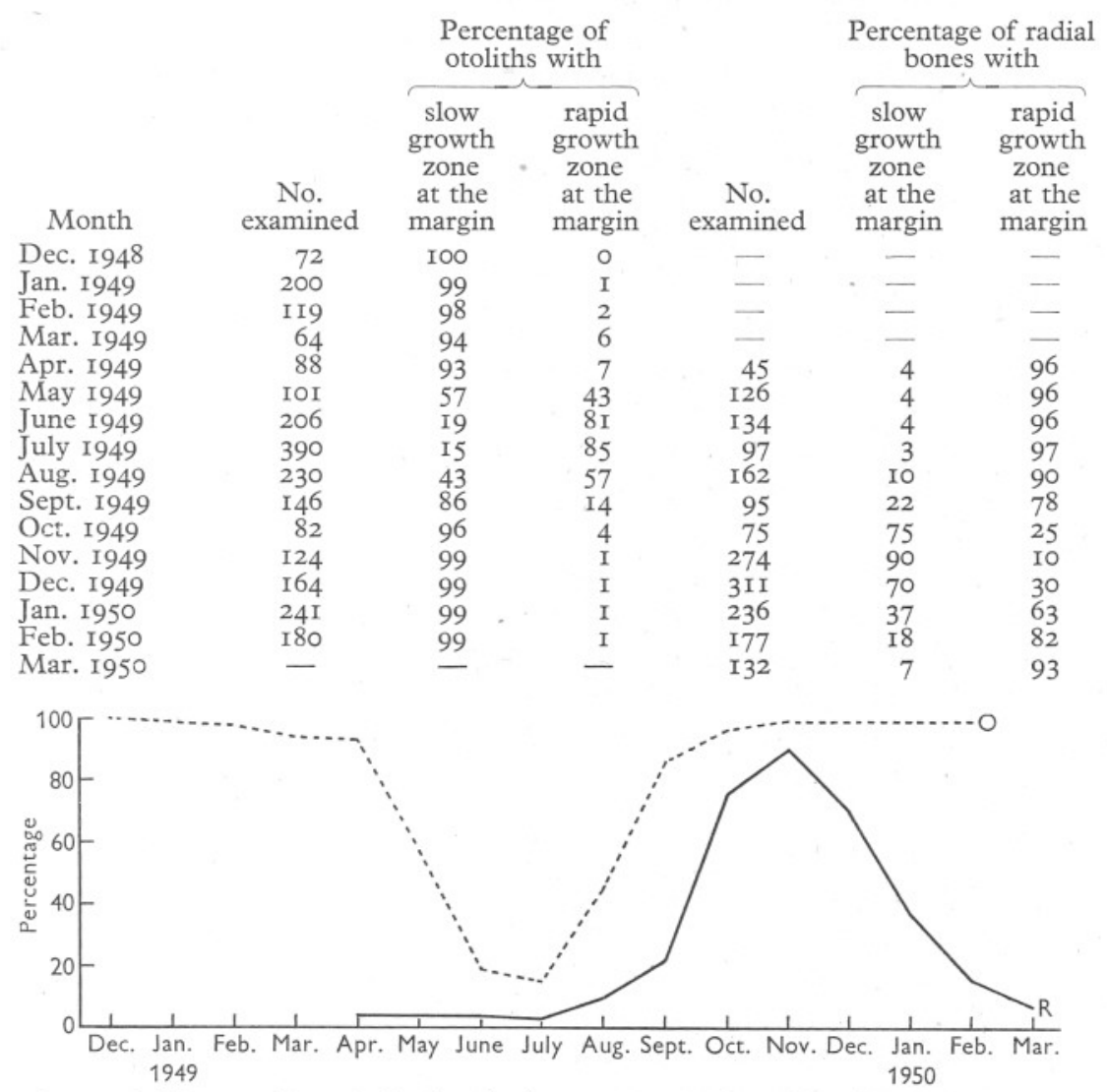

Text-fig. I. Callionymus lyra, $O$ (broken line), percentages of otoliths with transparent (slow growth) zone at margin, from December I 948 till February 1950. $R$ (continuous line), percentages of radial bones with slow growth zone at margins, from April 1949 till March 1950.

from specimens of various ages of both sexes have been examined, over a period of I5 months, from December I 948 to February I950 inclusive. The results confirm that the rings on the otoliths are formed annually, as there is a complete turning over of one sort of margin to the other during a certain period of the year (Table I; Text-fig. I). The opaque rings are laid down cover- 
ing the outer margin of the transparent zone during the summer months. It is a gradual increase in intensity of calcification rather than an increase in width during a short period. The transparent zone begins to appear after July, and the percentage of otoliths with the transparent margin reaches its peak $(99-100 \%)$ during the winter and early spring. By reading the rings on the otoliths the age and the particular year group to which a fish belongs can be determined without difficulty. Nevertheless, the margins of the rings are very diffuse and the size of the otoliths is subject to great variation. It is very difficult to fix the centre and the line of growth. Although the otolith has been used successfully in reading the age of the fish, it is not practicable to measure it for back-calculation of growth rate. Soon my attention turned towards the other skeletal structures of the fish, since many bones in other fishes have been widely used for age determination (see Menon, I950).

\section{Age and Rate of Growth from the Second Radial Bone}

On the vertebrae, coracoid, hypural and radials of C. lyra, there are very obvious alternating transparent and opaque zones, as found also in some bones of other fishes. After careful study, the zones on the second radial were found to be very constant, and the number of zones had a definite relationship with that on the otoliths of the same specimen. This bone was therefore selected for further study.

As a result of the great expansion of the pectoral girdle in C. lyra, the second radial bone becomes very flat and greatly enlarged. Its upper and lower surfaces are ossified, and in between the surface layers is the cartilage. During the autumn and winter the margin of the bone becomes almost completely ossified. Thus the narrow, ossified zone (i.e. the slow growth zone or winter ring) is formed.

\section{Method of Preparation}

The method of preparing the bone is very easy. After the specimens are measured and numbered, the complete right pectoral girdles are removed one by one with a pair of dissecting scissors, and put into numbered glass dishes. Then they are dipped into a hot bath of water at $70-80^{\circ} \mathrm{C}$. for $2-3 \mathrm{~min}$. After this simple treatment, the complete girdle can readily be cleaned with a cloth between the fingers or in a pair of curved forceps. The pectoral girdles of small specimens less than about $80 \mathrm{~mm}$. long are rather delicate, and must be carefully cleaned with forceps under the dissecting microscope, after which they are placed in labelled envelopes and left to dry.

\section{Line of Growth and Method of Measurement}

The distal half of the radial bone grows in three directions, as shown in Text-fig. 2. The centre of growth of the bone is very clear. If a straight line is drawn from the centre towards the angle of the bone, it crosses all the angles 
of the ossified rings. The measurements taken were along this line, the intervals $L_{1}, L_{2}, L_{3}$, etc., representing successive annual increments.

Since the radial is a cartilage bone, it shrinks a great deal after drying. The surface is no longer flat and the zones have lost their original shape. Therefore the radial bone of this fish has to be soaked for one to several days before

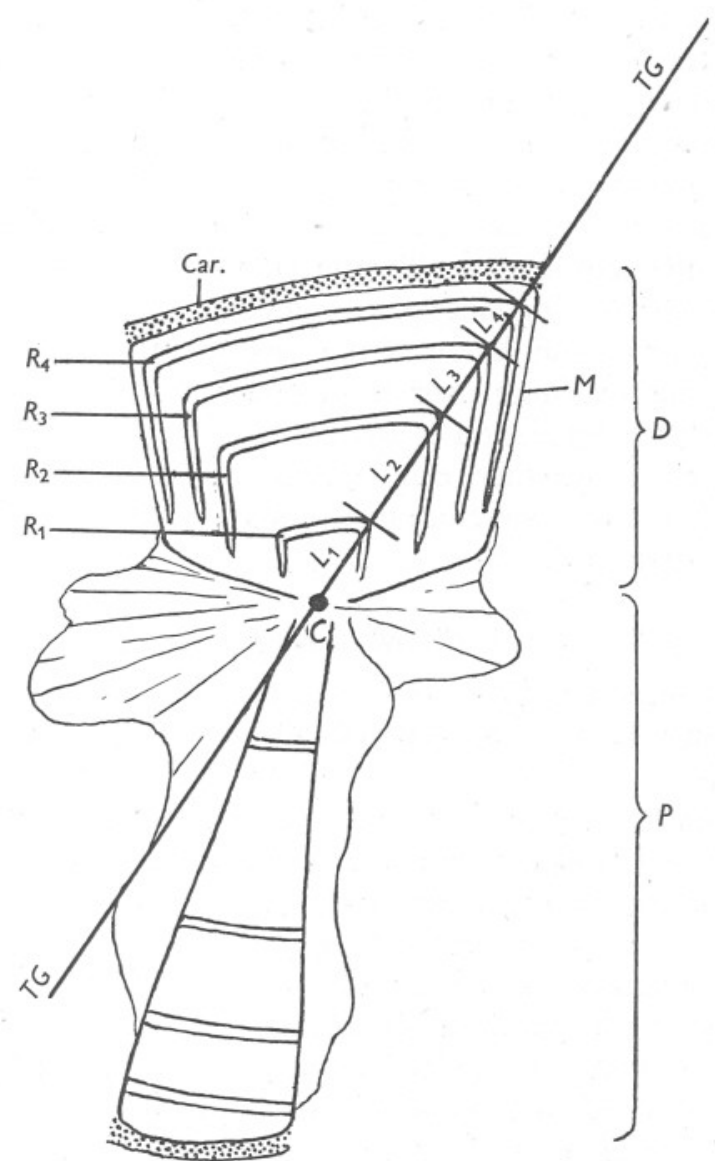

Text-fig. 2. The second radial bone of Callionymus lyra L. Diagram showing the theoretical growth line, and the way of measuring the length of the bone and the annual increments at different ages. $T G$, the hypothetical line of growth; $R_{1}$ to $R_{4}$, the annual rings; $C$, the centre of growth; $L_{1}, L_{2}, L_{3}$ and $L_{4}$, the first, second, third and fourth years' growth of the second radial bone; Car., cartilage layer; $M$, margin of the bone.

measuring. After this treatment the bone recovers its former size and shape, and the rings become as clear as if the bone were fresh. As the radial bone is not thin enough for projecting, it was measured under a low-power microscope with an eye-piece micrometer. 


\section{Validity of the Zones for Age Determination}

The main evidence supporting the validity of age determination from the second radial in this fish is that the rings on the bone are formed annually.

Monthly observations on the nature of the margins of the second radial were carried out over one complete year. Altogether I860 radials were examined specially for this test. The results obtained, together with those of the otoliths, are given in Table I and Text-fig. I. The data reveal two important points: (i) that there is a nearly complete turning over in a certain period of the year from one kind of margin to the other, and (ii) that there is also a definite agreement between the number of rings on the radial and that on the otoliths. In the second radial bone the narrow ossified zone (the slow-growth zone or winter ring) begins to appear in September. Its percentage occurrence is highest in November and falls rapidly after December. Usually, in young fish, the formation of the first ring takes place comparatively early, whereas in some of the mature fish the completion of the rings is much delayed. Therefore, there is no complete turning over from one kind of margin to the other throughout the entire population at any period.

From the above evidence there can be no doubt that the zones on the second radial are annual, and it is therefore concluded that the second radial is valid for age determination in this fish.

\section{Results of Growth MeAsurements}

Altogether I059 second radials from male fish and 627 from females were measured. Among the 1059 male radials 876 were from immature and 183 from mature fish.

The mean lengths of both body and radial at each $5 \mathrm{~mm}$. group in the immature males and females are given in Table II. When the mean radial lengths are plotted against the mean body lengths all the points lie practically along a straight line, as shown in Text-fig. 3 .

The snout in mature males is greatly prolonged and subjected to great variation. As its length is correlated with the state of sexual maturity and is not in direct proportion to the body length, correction must be made in total length measurements for the excess of snout length (see p. 289). After this correction has been made and the mature males regrouped, the proportion of the mean lengths of the radials and the corrected body length in different length groups came into agreement with those of the immature males and the females (Table VI; Text-fig. 3).

By graphic method the formula for the correlation curve of the radial length and the body length in this fish is as follows

$$
R=0.04+0.0199 B,
$$

where $R$ is the length of the radial and $B$ is the body length; both measured in $\mathrm{mm}$. By using this formula the theoretical lengths of either radial bone or 
the body length of each $5 \mathrm{~mm}$. group above $35 \mathrm{~mm}$. can be worked out, given one or the other. In Table II the calculated body lengths (given the observed radial bone lengths) are listed for immature males and females, and in Table VI for mature males. The differences between the empirical lengths and

Table II. Mean Lengths of the Second Radial in Relation to the Mean Length of Fish at the Different Length Groups

\begin{tabular}{|c|c|c|c|c|c|c|c|c|c|c|}
\hline \multirow{3}{*}{$\begin{array}{l}\text { Length } \\
\text { group } \\
\text { (mm.) }\end{array}$} & \multicolumn{5}{|c|}{ Immature males } & \multicolumn{5}{|c|}{ Females } \\
\hline & \multirow{2}{*}{$\begin{array}{l}\text { No. } \\
\text { of } \\
\text { fish }\end{array}$} & \multirow{2}{*}{$\begin{array}{l}\text { Mean } \\
\text { body } \\
\text { length } \\
(\mathrm{mm} .)\end{array}$} & \multicolumn{2}{|c|}{$\begin{array}{c}\text { Length of } \\
\text { 2nd radial } \\
\text { (mm.) }\end{array}$} & \multirow{2}{*}{$\begin{array}{c}\text { Theoretical } \\
\text { body } \\
\text { length } \\
\text { (mm.) }\end{array}$} & \multirow{2}{*}{$\begin{array}{l}\text { No. } \\
\text { of } \\
\text { fish }\end{array}$} & \multirow{2}{*}{$\begin{array}{c}\text { Mean } \\
\text { body } \\
\text { length } \\
(\mathrm{mm} .)\end{array}$} & \multicolumn{2}{|c|}{$\begin{array}{c}\text { Length of } \\
\text { 2nd radial } \\
\text { (mm.) }\end{array}$} & \multirow{2}{*}{$\begin{array}{c}\text { Theoretica } \\
\text { body } \\
\text { length } \\
(\mathrm{mm} .)\end{array}$} \\
\hline & & & mean & $\sigma$ & & & & mean & $\sigma$ & \\
\hline 20 & I & $20 \cdot 0$ & 0.48 & - & $22 \cdot I$ & 0 & - & - & 一 & - \\
\hline 25 & 0 & - & - & - & - & o & - & 一 & - & 一 \\
\hline 30 & 4 & $33 \cdot 2$ & 0.73 & 0.03 & $34 \cdot 7$ & 4 & $32 \cdot 8$ & 0.74 & 0.02 & $35 \cdot 2$ \\
\hline 35 & 5 & $37 \cdot 2$ & 0.80 & 0.06 & $38 \cdot 2$ & 12 & $36 \cdot 8$ & 0.79 & 0.07 & $37 \cdot 7$ \\
\hline 40 & I5 & $42 \cdot 8$ & $0.9 \mathrm{I}$ & 0.05 & $43 \cdot 7$ & 19 & $42 \cdot I$ & 0.91 & 0.05 & $43 \cdot 7$ \\
\hline 45 & II & $47 \cdot \mathrm{I}$ & 0.98 & 0.02 & $47 \cdot 2$ & 9 & $46 \cdot 8$ & 0.99 & 0.05 & $47 \cdot 7$ \\
\hline 50 & 7 & $57 \cdot 4$ & I.04 & 0.05 & $50 \cdot 3$ & 6 & $52 \cdot 0$ & $I \cdot I O$ & 0.05 & $53 \cdot 3$ \\
\hline 55 & 7 & 58.6 & $\mathrm{I} \cdot \mathrm{I} 7$ & 0.07 & $56 \cdot 8$ & 6 & $56 \cdot 7$ & $I \cdot 20$ & 0.05 & $58 \cdot 3$ \\
\hline 60 & 4 & $62 \cdot 7$ & $I \cdot 28$ & 0.08 & $62 \cdot 3$ & 7 & 63.1 & $I \cdot 33$ & 0.04 & 64.8 \\
\hline 65 & 6 & $67 \cdot 2$ & $I \cdot 39$ & 0.06 & $67 \cdot 8$ & Io & $66 \cdot 6$ & $I \cdot 38$ & 0.06 & $67 \cdot 3$ \\
\hline 70 & 7 & $72 \cdot 0$ & $I \cdot 43$ & 0.05 & $69 \cdot 8$ & 6 & 73.0 & $\mathrm{I} \cdot 5 \mathrm{I}$ & O.I I & 73.9 \\
\hline 75 & 9 & $76 \cdot 7$ & $I \cdot 56$ & 0.07 & $76 \cdot 4$ & I7 & $76 \cdot 6$ & $I \cdot 56$ & 0.10 & $76 \cdot 4$ \\
\hline 80 & 9 & $82 \cdot 6$ & $I .65$ & 0.07 & 80.9 & I4 & $82 \cdot 0$ & $I \cdot 68$ & 0.08 & $82 \cdot 4$ \\
\hline 85 & I5 & $87 \cdot 0$ & $\mathrm{I} \cdot 72$ & 0.06 & $84: 4$ & 24 & $87 \cdot 2$ & $I \cdot 73$ & 0.07 & 84.9 \\
\hline 90 & 32 & $92 \cdot 4$ & $\mathrm{I} \cdot 8 \mathrm{I}$ & 0.09 & $88 \cdot 9$ & 46 & $9 \mathrm{I} \cdot 8$ & $I \cdot 84$ & 0.08 & $90 \cdot 5$ \\
\hline 95 & 43 & $97^{\circ} \circ$ & $\mathrm{I} \cdot 89$ & 0.07 & $93 \cdot 0$ & 46 & $97 \cdot 2$ & $I \cdot 95$ & 0.09 & 96.0 \\
\hline IOO & 45 & $102 \cdot 0$ & 2.00 & 0.08 & 98.5 & 40 & 102.0 & 2.04 & 0.09 & 100.5 \\
\hline I05 & 55 & $107 \cdot 4$ & $2 \cdot 10$ & 0.08 & 103.5 & 43 & $106 \cdot 8$ & 2.12 & 0.09 & IO4.5 \\
\hline IIO & 50 & I I I. 9 & $2 \cdot 19$ & 0.10 & 108.0 & 32 & I I I 99 & $2 \cdot 26$ & 0.10 & III. 6 \\
\hline I I 5 & 43 & I I $7^{\circ} 0$ & $2 \cdot 3 I$ & 0.08 & I I 4. I & 35 & I I $7^{\circ} \mathrm{O}$ & $2 \cdot 36$ & O.II & II 6.6 \\
\hline 120 & 37 & $I 22 \cdot I$ & 2.44 & 0.10 & 120.6 & 44 & $\mathrm{I} 2 \mathrm{I} \cdot 8$ & $2 \cdot 48$ & 0.10 & 122.6 \\
\hline I 25 & 25 & $127^{\circ} 0$ & 2.54 & 0.10 & 125.6 & 38 & $127 \cdot 0$ & 2.58 & O.II & $\mathrm{I} 27^{\circ} 6$ \\
\hline I3O & 40 & I3I. 6 & 2.62 & O.I I & 129.6 & 20 & $132 \cdot 3$ & 2.68 & 0.09 & I 32.7 \\
\hline I35 & 30 & I $37^{\circ}$ I & 2.79 & 0.12 & $138 \cdot 2$ & 29 & 136.6 & $2 \cdot 8 I$ & O.II & I 39.2 \\
\hline I 40 & 23 & I 42.9 & 2.88 & 0.09 & $142 \cdot 7$ & 25 & I $4 \mathrm{I} \cdot 6$ & 2.90 & O.I4 & 143.7 \\
\hline I 45 & 36 & I 46.8 & $2 \cdot 92$ & 0.13 & I 44.7 & $2 \mathrm{I}$ & 146.8 & 3.01 & 0.18 & I $49 \cdot 2$ \\
\hline I 50 & 35 & $15 \mathrm{I} \cdot 7$ & 3.04 & 0.13 & I50.8 & I8 & I $5 \mathrm{I} \cdot 5$ & $3 \cdot 16$ & O.II & 156.8 \\
\hline I55 & 30 & I 56.3 & 3.17 & 0.10 & I 57.3 & I3 & 156.7 & $3 \cdot 25$ & 0.13 & $\mathrm{I} 6 \mathrm{I} \cdot 3$ \\
\hline 160 & 36 & 162.0 & 3.31 & 0.14 & 164.3 & 19 & $161 \cdot 5$ & 3.29 & 0.14 & 163.3 \\
\hline I65 & 42 & I66.9 & $3 \cdot 36$ & 0.15 & 166.8 & 7 & 167.0 & $3 \cdot 38$ & 0.10 & 167.8 \\
\hline 170 & 49 & $172 \cdot 6$ & 3.43 & O.I4 & I 70.4 & IO & $I 7 I \cdot I$ & 3.50 & 0.18 & 173.9 \\
\hline I75 & 39 & I 76.4 & 3.50 & 0.13 & I 73.9 & 2 & 176.5 & 3.59 & 0.24 & I 78.4 \\
\hline 180 & 37 & $18 \mathrm{I} \cdot 5$ & 3.60 & 0.13 & I 78.9 & 3 & 183.0 & 3.57 & 0.08 & I 77.4 \\
\hline I85 & 25 & 186.4 & 3.68 & 0.15 & 182.9 & 2 & 185.0 & $3.8 \mathrm{I}$ & 0.04 & I 89.4 \\
\hline I90 & I 2 & I9I. 6 & 3.89 & 0.16 & 193.5 & - & - & - & - & - \\
\hline I95 & 4 & 196.5 & 3.97 & 0.19 & 197.5 & - & - & 一 & - & - \\
\hline 200 & 7 & $20 \mathrm{I} \cdot 2$ & 3.92 & 0.16 & $195^{\circ} 0$ & - & - & - & - & - \\
\hline
\end{tabular}

the calculated lengths of the body are less than $5 \mathrm{~mm}$. except at a few points.

An analysis of the length frequency in relation to the number of rings on the 2nd radial bone shows that the male may attain an age of 5 years (with four complete ossified winter rings), while the females may live 2 years longer 


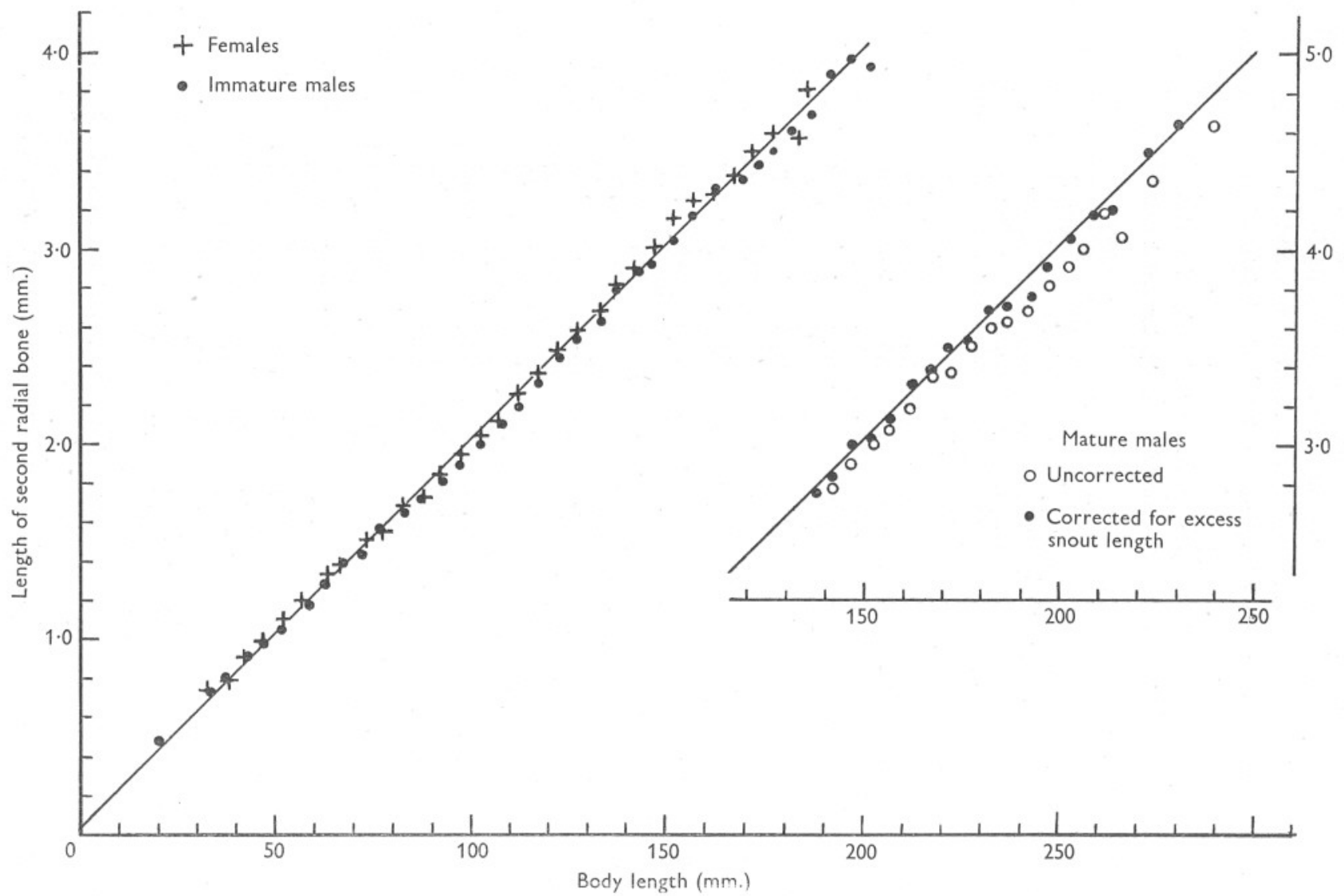

Text-fig. 3. Relation between body length and length of the second radial bone.

The graph line in the inset is identical with that in the main diagram, showing that the 'corrected' males conform with the females and immatures. 
(with six complete ossified winter rings). However, the males grow much more quickly and to a larger size than the females (Table III).

It is also shown that among the I059 radials from male fish, I024 have one or more ossified winter rings; 680 radials have two or more; I64 radials have three or more; and only six radials have four complete ossified winter rings. If the mean lengths of the Ist, 2 nd, 3 rd and 4 th rings are worked by backcalculation derived from the radial, the annual increment of the body length can be obtained irrespective of the actual length of the fish. Similarly, the annual increment of the body length in females at different ages can be calculated (Tables IV and V; Text-fig. 4).

The mean lengths of both the body and the radial of the mature males are entered in Table VI. When mean lengths of radials are plotted against the mean fish lengths, nearly all the points are far below the correlation curve for the immature males and the females (Text-fig. 3). If the snout length in the mature males be corrected according to the following averages derived from the immature males, all the points lie very close to the correlation curve of mean radial length and body length of both immature males and females:

$$
\text { snout length }(\mathrm{mm} .)=-0.3625+0.1275 \times \text { body length. }
$$

\section{Natural Death of the Spent Males}

During the spring and summer of 1949, some interesting phenomena were observed. First, sexual maturity in the males was not directly related to the length of the body, since the spawning males varied from about I30 $\mathrm{mm}$. to nearly as long as $240 \mathrm{~mm}$., and at the same time many large immature males were found in the catches (Table VII). Secondly, the majority of the spawning males lost weight very quickly after the breeding season started, generally in the latter part of January off Plymouth, and their secondary sexual characters became extremely prominent. Thirdly, the majority of spent males suddenly disappeared after June and July. This sudden disappearance could be explained in three ways: (i) by degeneration or reabsorption of all the secondary sexual characters, (ii) by migration of the spent males to deeper waters after the breeding season, and (iii) by natural death of the spent males after the breeding season. However, there was no evidence to support the first two possibilities.

An analysis of the age of all the males collected from April I949 to March I950 inclusive, shows that the spawning males clearly fall into three age groups and that all the year round there are mature males; but the percentages of such fish exceeding $120 \mathrm{~mm}$. in length (the size of the smallest mature males) showed a tremendous seasonal change. It was as low as $4.4 \%$ in October and as high as $78.1 \%$ in March (Table VI). Throughout the 20 months of direct observations on the catches, the gradual changes in the development of the secondary sexual characters in the males could easily be followed, and there was no indication of any recovery of the body condition 
Table III. Length Frequencies of Fish and Relation to Number of Ossified Rings ON THE SECOND RAdial Bones

Mature males enumerated separately in heavy type

\begin{tabular}{|c|c|c|c|c|c|c|c|c|c|c|c|c|c|c|}
\hline \multirow{2}{*}{$\begin{array}{l}\text { Length } \\
\text { group } \\
\text { (mm.) }\end{array}$} & \multicolumn{6}{|c|}{ Males. Ossified rings on second radials } & \multicolumn{8}{|c|}{ Females. Ossified rings on second radials } \\
\hline & $\circ$ & $\mathbf{I}+$ & $2+$ & $3+$ & $4^{+}$ & Total & $\circ$ & $\mathbf{I}+$ & $2+$ & $3+$ & $4+$ & $5+$ & $6+$ & Total \\
\hline 20 & I & $\bar{z}$ & $=$ & $=$ & $=$ & I & $\circ$ & - & - & - & - & - & - & - \\
\hline $\begin{array}{l}25 \\
30\end{array}$ & $\begin{array}{l}\circ \\
4\end{array}$ & 二 & 二 & 二 & 二 & $\circ$ & $\circ$ & - & 二 & 二 & 二 & - & - & - \\
\hline 35 & $\begin{array}{l}4 \\
5 \\
5\end{array}$ & 二 & $=$ & 二 & 二 & $\begin{array}{l}4 \\
5\end{array}$ & $\begin{array}{l}3 \\
4\end{array}$ & $\begin{array}{l}\mathrm{I} \\
8\end{array}$ & 二 & 二 & 二 & 二 & 二 & ${ }_{12}^{4}$ \\
\hline 40 & II & 4 & 二 & 二 & $=$ & 15 & $\begin{array}{l}14 \\
14\end{array}$ & 5 & - & - & - & 二 & 二 & $\begin{array}{l}12 \\
19\end{array}$ \\
\hline $\begin{array}{l}45 \\
50\end{array}$ & $\begin{array}{l}7 \\
2\end{array}$ & $\begin{array}{l}4 \\
5\end{array}$ & 二 & 二 & $=$ & II & 5 & 4 & - & $=$ & 二 & - & - & 9 \\
\hline 55 & 3 & 5 & 二 & 二 & 二 & 8 & $\stackrel{2}{\circ}$ & $\begin{array}{l}4 \\
6\end{array}$ & 二 & 二 & 二 & 二 & $=$ & 6 \\
\hline 60 & I & 3 & 二 & $=$ & $=$ & 4 & o & 6 & I & 二 & 二 & 二 & 二 & $\begin{array}{l}6 \\
7\end{array}$ \\
\hline $\begin{array}{l}65 \\
70\end{array}$ & I & $\begin{array}{l}5 \\
7\end{array}$ & 二 & $=$ & $=$ & 6 & $\begin{aligned}-1 \\
0\end{aligned}$ & 9 & $\circ$ & $=$ & 二 & 二 & - & 10 \\
\hline 75 & $=$ & 7 & 2 & 二 & $=$ & $\begin{array}{l}7 \\
9\end{array}$ & $\stackrel{\circ}{I}$ & $\begin{array}{r}0 \\
14\end{array}$ & $\begin{array}{l}0 \\
2\end{array}$ & 二 & 二 & $=$ & 二 & 6 \\
\hline 80 & 二 & 7 & 2 & - & - & 9 & -1 & 8 & $\begin{array}{l}2 \\
6\end{array}$ & 二 & 二 & 二 & = & 17 \\
\hline $\begin{array}{l}85 \\
90\end{array}$ & 二 & $\begin{array}{l}12 \\
19\end{array}$ & 3 & $\bar{z}$ & $=$ & 15 & $=$ & I4 & ro & 二 & - & 二 & 三 & $\begin{array}{l}\begin{array}{l}14 \\
24\end{array} \\
24\end{array}$ \\
\hline $\begin{array}{l}90 \\
95\end{array}$ & 二 & $\begin{array}{l}19 \\
37\end{array}$ & $\begin{array}{r}13 \\
6\end{array}$ & 二 & $=$ & $\begin{array}{l}32 \\
43\end{array}$ & 二 & $\begin{array}{l}30 \\
26\end{array}$ & $\begin{array}{l}16 \\
20\end{array}$ & 二 & $=$ & 二 & 二 & $\begin{array}{l}24 \\
46 \\
46\end{array}$ \\
\hline 100 & - & 32 & 13 & - & $=$ & $\begin{array}{l}43 \\
45\end{array}$ & 二 & $\begin{array}{l}26 \\
23\end{array}$ & $\begin{array}{l}20 \\
17\end{array}$ & 二 & $=$ & 二 & 二 & 46 \\
\hline I05 & $=$ & $\begin{array}{l}36 \\
36\end{array}$ & 19 & 二 & - & $\begin{array}{l}43 \\
55\end{array}$ & - & 26 & $\begin{array}{l}17 \\
17\end{array}$ & 二 & 二 & 二 & 二 & \\
\hline $\begin{array}{l}110 \\
115\end{array}$ & 二 & $\begin{array}{l}36 \\
32\end{array}$ & I4 & $=$ & $\bar{\pi}$ & 50 & 二 & 17 & 15 & - & - & 二 & 二 & $\begin{array}{l}43 \\
32\end{array}$ \\
\hline $\begin{array}{l}115 \\
120\end{array}$ & 二 & $\begin{array}{l}32 \\
26\end{array}$ & $\begin{array}{l}\text { II } \\
\text { II }\end{array}$ & 二 & 二 & 43 & 二 & ${ }^{14}$ & $\begin{array}{l}15 \\
30\end{array}$ & 6 & 二 & - & & $\begin{array}{l}32 \\
35 \\
35\end{array}$ \\
\hline 125 & - & $\begin{array}{l}20 \\
15\end{array}$ & $\begin{array}{l}11 \\
\text { 10 }\end{array}$ & 二 & 二 & $\begin{array}{l}37 \\
25\end{array}$ & 二 & $\begin{array}{l}6 \\
8\end{array}$ & $\begin{array}{l}30 \\
24\end{array}$ & 8 & $\overline{-}$ & - & - & $\begin{array}{l}35 \\
44\end{array}$ \\
\hline 130 & 二 & 20 & 20 & 二 & 二 & $\begin{array}{l}25 \\
40\end{array}$ & 二 & 2 & $\begin{array}{l}24 \\
\mathrm{~T} 4\end{array}$ & 6 & $\bar{T}$ & - & - & $\begin{array}{l}44 \\
38\end{array}$ \\
\hline 135 & 二 & 10 & 17 & 3 & - & 30 & - & $\mathrm{I}$ & $\begin{array}{l}14 \\
18\end{array}$ & $\begin{array}{l}3 \\
9\end{array}$ & I & 二 & 二 & 20 \\
\hline $\begin{array}{l}140 \\
145\end{array}$ & 二 & $7+1$ & $15+6$ & I & - & 30 & - & I & I0 & 14 & - & - & 二 & $\begin{array}{l}29 \\
25\end{array}$ \\
\hline $\begin{array}{l}145 \\
I 50\end{array}$ & 二 & $\begin{array}{l}8+\mathbf{I} \\
2+0\end{array}$ & $\begin{array}{l}26+6 \\
32+8\end{array}$ & $2+1$ & $=$ & 44 & 二 & $\mathrm{I}$ & 7 & 12 & I & - & - & 21 \\
\hline 155 & $=$ & $\begin{array}{l}2+0 \\
0+0\end{array}$ & $\begin{array}{l}32+8 \\
30+8\end{array}$ & $\begin{array}{l}\mathrm{I}+3 \\
\mathrm{O}+5\end{array}$ & 二 & 46 & 二 & $=$ & 2 & 15 & I & $=$ & 二 & 18 \\
\hline 160 & - & $I+I$ & $30+3$ & $5+6$ & - & $\begin{array}{l}43 \\
46\end{array}$ & 二 & 二 & ${ }_{1}^{4}$ & $\begin{array}{l}6 \\
\text { II }\end{array}$ & $\begin{array}{l}3 \\
7\end{array}$ & 二 & 二 & 13 \\
\hline $\begin{array}{l}165 \\
170\end{array}$ & $=$ & I_- & $\begin{array}{l}40+3 \\
4 I+6\end{array}$ & $\begin{array}{l}\mathrm{I}+\mathbf{I I} \\
8+\mathbf{0}\end{array}$ & $=$ & 56 & 二 & 二 & - & 2 & 5 & - & $\mathrm{I}$ & 7 \\
\hline $\begin{array}{l}170 \\
175\end{array}$ & 二 & 二 & $\begin{array}{l}4 \mathrm{I}+6 \\
35+8\end{array}$ & $8+9$ & 二 & 64 & $\bar{z}$ & $=$ & $=$ & 3 & 5 & $\mathrm{I}$ & 二 & 10 \\
\hline $\begin{array}{l}180 \\
180\end{array}$ & - & 二 & $\begin{array}{c}35+8 \\
31+0\end{array}$ & $\begin{array}{l}4+17 \\
6+7\end{array}$ & $\bar{x}$ & $\begin{array}{l}64 \\
45\end{array}$ & 二 & 二 & 二 & $=$ & 2 & - & 二 & 2 \\
\hline 185 & $=$ & 二 & $2 \mathrm{I}+\mathrm{I}$ & $4+\mathbf{I I}$ & 二 & 37 & - & $=$ & $\bar{二}$ & 二 & $\begin{array}{l}1 \\
2\end{array}$ & -2 & 二 & $\begin{array}{l}3 \\
2\end{array}$ \\
\hline $\begin{array}{l}190 \\
195\end{array}$ & 二 & 二 & $\begin{array}{r}10+2 \\
2+3\end{array}$ & $\begin{array}{l}2+10 \\
2+10\end{array}$ & 二 & 24 & $=$ & $=$ & $=$ & $=$ & 二 & 二 & - & - \\
\hline 200 & 二 & 二 & $\begin{array}{l}2+3 \\
7+\mathbf{Y}\end{array}$ & $\begin{array}{c}2+10 \\
9\end{array}$ & 2 & $\begin{array}{l}17 \\
19\end{array}$ & $=$ & 二 & $=$ & 二 & 二 & $\bar{z}$ & 二 & 二 \\
\hline 205 & 二 & 二 & 二 & 7 & $\mathbf{I}$ & 8 & - & 二 & $\bar{Z}$ & 二 & 二 & 二 & 二 & 二 \\
\hline $\begin{array}{l}210 \\
215\end{array}$ & 二 & 二 & 二 & 3 & $\sqrt{x}$ & 3 & 二 & $=$ & $=$ & 二 & 二 & - & - & - \\
\hline 220 & 二 & 二 & 二 & $\begin{array}{l}5 \\
4\end{array}$ & $\begin{array}{l}\mathbf{I} \\
\mathbf{I}\end{array}$ & $\begin{array}{l}6 \\
5\end{array}$ & 二 & 二 & 二 & 二 & 二 & 二 & 二 & 二 \\
\hline 225 & 二 & 二 & 二 & - & 二 & 0 & - & - & - & - & - & - & - & 二 \\
\hline $\begin{array}{l}230 \\
235\end{array}$ & 二 & 二 & 二 & - & $=$ & $\circ$ & 二 & $=$ & 二 & - & - & - & - & - \\
\hline $\begin{array}{r}235 \\
\text { Totals }\end{array}$ & 35 & $341^{-}$ & ${ }^{-1}$ & ${ }^{I}$ & - & I & - & $\overline{-}$ & - & - & - & - & - & - \\
\hline 1 otals & 35 & 3 & $\begin{array}{ll}461 & 55\end{array}$ & $39 \quad 119$ & $\overline{6}$ & ros9 & $\overline{30}$ & $2 \overline{240}$ & $2 \overline{229}$ & $\overline{95}$ & $\overline{29}$ & $\overline{3}$ & $\bar{x}$ & $6 \overline{27}$ \\
\hline
\end{tabular}


of the spent males or reabsorption of the secondary sexual characters. The most distinct feature of the secondary sexual characters other than coloration is the great prolongation of the snout and of all the median fins, including the

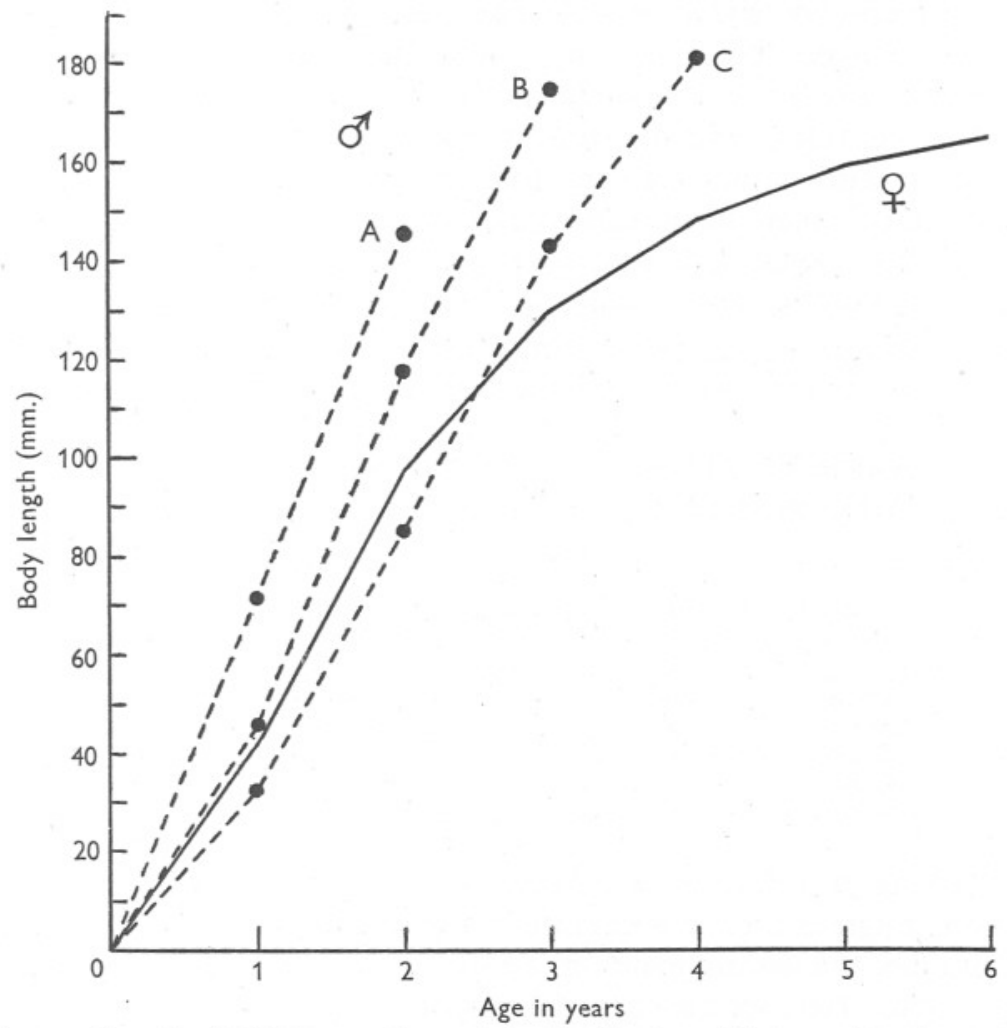

Text-fig. 4. Growth of Callionymus lyra. $\hat{o}$ (broken line), A, third-year breeder; B, fourthyear breeder; c, fifth-year breeder. $\&$ (continuous line), mixed.

Table IV. Mean Length of Successive Annual Rings

\begin{tabular}{|c|c|c|c|c|c|c|c|c|}
\hline & \multicolumn{4}{|c|}{ Male } & \multicolumn{4}{|c|}{ Female } \\
\hline & No. & Range & $\begin{array}{l}\text { Mean } \\
\text { length } \\
(\mathrm{mm} .)\end{array}$ & S.D. & No. & Range & $\begin{array}{l}\text { Mean } \\
\text { length } \\
(\mathrm{mm} .)\end{array}$ & S.D. \\
\hline $\begin{array}{l}\text { Ist ring } \\
\text { 2nd ring }\end{array}$ & $\begin{array}{r}1024 \\
680\end{array}$ & $\begin{array}{l}0.39-1.90 \\
0.68-2.08\end{array}$ & $\begin{array}{l}I \cdot 04 \\
I \cdot 37\end{array}$ & $\begin{array}{l}0.28 \\
0.27\end{array}$ & $\begin{array}{l}597 \\
357\end{array}$ & $\begin{array}{l}0.40-I .90 \\
0.58-I .98\end{array}$ & $\begin{array}{l}0.88 \\
I \cdot 14\end{array}$ & $\begin{array}{l}0.27 \\
0.26\end{array}$ \\
\hline 3 rd ring & I59 & $0.30-\mathrm{r} \cdot 88$ & $\mathrm{I} \cdot \mathrm{IO}$ & 0.31 & $\begin{array}{l}351 \\
128\end{array}$ & $0.22-1 \cdot 40$ & 0.69 & 0.28 \\
\hline $4^{\text {th }}$ ring & 6 & $0.46-\mathrm{I} \cdot 04$ & $0.8 \mathrm{I}$ & 0.23 & 33 & $0.10-0.80$ & $0.4 \mathrm{I}$ & 0.19 \\
\hline 5 th ring & - & - & - & - & 4 & $0.20-0.36$ & 0.25 & 0.36 \\
\hline 6 th ring & - & - & - & - & I & - & 0.16 & 0.00 \\
\hline
\end{tabular}

dorsal, anal and caudal fins. The prolongation of the snout is mainly effected by the elongation of the process of the premaxillary (Günther, I86I, pp. I40-2). For example, the premaxillary of a spent male, I66 mm. long, 
collected in May 1949, reached $28 \mathrm{~mm}$., while an immature one $168 \mathrm{~mm}$. long, collected in the same month, was only $22 \mathrm{~mm}$. long. The length of the first dorsal fin-ray of the former was $125 \mathrm{~mm}$. and of the latter $5 \mathrm{I} \mathrm{mm}$. In two other specimens, one a mature male, $204 \mathrm{~mm}$. long (May 1949), and the other an immature male, $201 \mathrm{~mm}$. long (November 1949), the lengths of the premaxillary were 40 and $29 \mathrm{~mm}$., and of the first dorsal fin-rays $\mathrm{I} 45$ and $95 \mathrm{~mm}$. respectively. Since the fin-ray and the ossified premaxillary are not epidermal structures, they are very different from the nuptial organ (or pearl organs) found in many fresh-water fishes, which can be dropped off after the breeding season (Kimura \& Tao, 1937) and the fleshy hump on the forehead of the cichlids (Cichlidae), which is absorbed after the breeding season (Norman, 1947, p. 301). The possibility of sudden absorption of the skeletal structure or of the greatly elongated fin-rays in this fish would seem impossible.

\begin{tabular}{|c|c|c|c|c|}
\hline \multirow[b]{2}{*}{$\begin{array}{l}\text { Towards the } \\
\text { end of }\end{array}$} & \multicolumn{2}{|c|}{ Male } & \multicolumn{2}{|c|}{ Female } \\
\hline & $\begin{array}{c}\text { Annual } \\
\text { increment }\end{array}$ & $\begin{array}{c}\text { Cumulative } \\
\text { length }\end{array}$ & $\begin{array}{c}\text { Annual } \\
\text { increment }\end{array}$ & $\begin{array}{c}\text { Cumulative } \\
\text { length }\end{array}$ \\
\hline Ist ring & $\begin{array}{l}50 \cdot 3 \\
66 \cdot 8\end{array}$ & $50 \cdot 3$ & $\begin{array}{l}42 \cdot 2 \\
55 \cdot 2\end{array}$ & $42 \cdot 2$ \\
\hline 2nd ring & $66 \cdot \overline{8}$ & II $7 \cdot$ I & $55 \cdot 3$ & 97.5 \\
\hline 3 rd ring & $53 \cdot 3$ & $170 \cdot 4$ & $32 \cdot 7$ & $130 \cdot 2$ \\
\hline 4th ring & 38.7 & $209 \cdot \mathrm{I}$ & 18.6 & I 48.8 \\
\hline 5 th ring & & - & 10.6 & 159.4 \\
\hline 6th ring & - & - & 6.0 & $\begin{array}{l}165.4 \\
16.4\end{array}$ \\
\hline
\end{tabular}

No marking experiments have been done to elucidate whether or not the spent males migrate into the deeper water after the breeding season. But the age composition of the mature males in the spring of 1949 is similar to that in the spring of 1950 . Here we may take the proportion of the spawning males in the month of April 1949 and those of March I950 for comparison. The numbers of the third-year, fourth-year and fifth-year breeders in April are IO, 2I and I; and in March I950 are 24, 52 and 3 respectively. If the spent males did come back to breed again, the age distribution of the spawning males in the spring of 1950 should have included many more fifth-year breeders. Attempts have been made to study the histological structures of the testis at different stages, and to find out how they are correlated with the secondary sexual characters and seasonal changes, but the data so obtained have not yet been analysed.

Turning to the positive evidence that natural death takes place in the males after the breeding season, the age and rate of growth of 153 spent males were studied in detail. These comprised forty third-year breeders (with two complete winter rings), I07 fourth-year breeders (with three complete winter rings), and six fifth-year breeders (with four complete rings). It was found that the rates of growth of these groups were very different (Table VIII, Text-fig. 4). In those males breeding in the third year the rate of growth was 
Table VI. Callionymus lyra, Mature Males. Lengths of Body and Second Radial Bone as Observed, and as Corrected for Excess SNout LENGTH

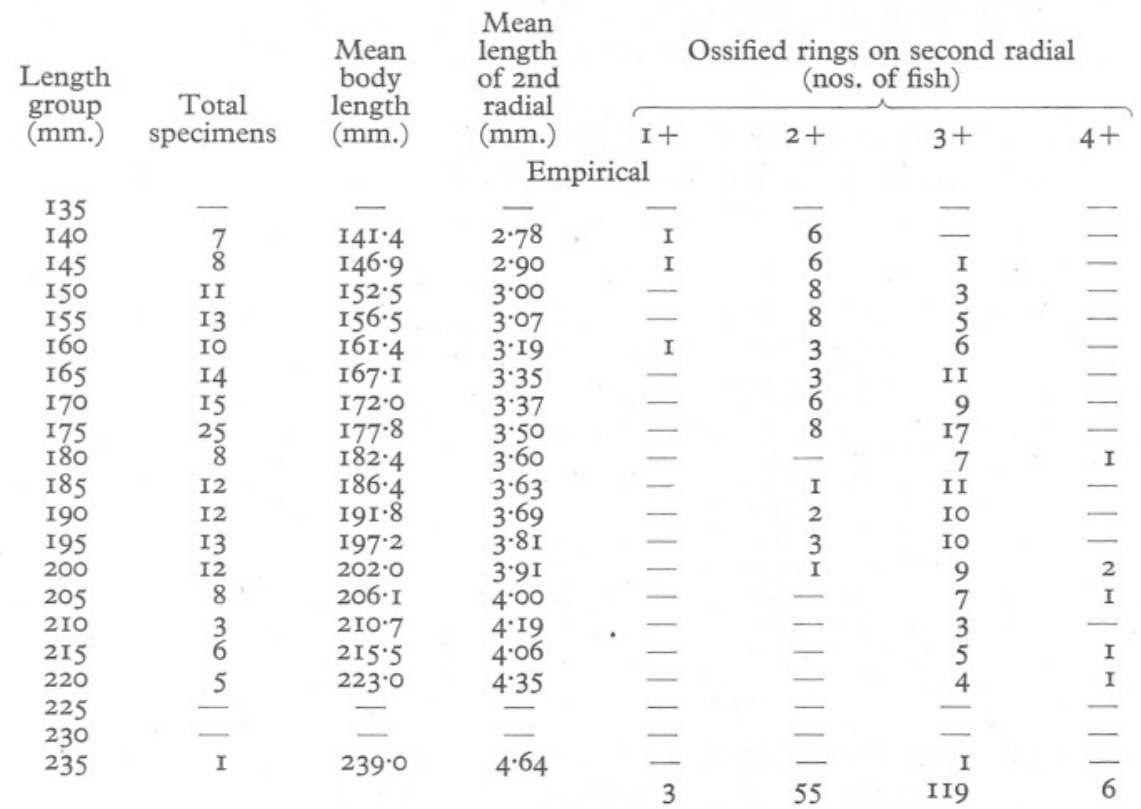

\begin{tabular}{rc}
3 & I38.0 \\
9 & I42.0 \\
7 & $147 \cdot 4$ \\
I5 & I5I.9 \\
II & I56.8 \\
I3 & $161 \cdot 9$ \\
I6 & I67.2 \\
9 & I7I.2 \\
27 & I76.9 \\
I5 & I8I.9 \\
7 & $186 \cdot 9$ \\
I9 & $192 \cdot 4$ \\
8 & $196 \cdot 6$ \\
I5 & $202 \cdot 6$ \\
3 & $208 \cdot 2$ \\
2 & $213 \cdot 0$ \\
\hline 3 & - \\
\hline & $220 \cdot 0$ \\
I & - \\
- & $230 \cdot 0$ \\
& -
\end{tabular}

Corrected

\begin{tabular}{|c|c|c|c|c|}
\hline $2 \cdot 75$ & I & 2 & - & - \\
\hline 2.83 & - & 9 & - & - \\
\hline 2.99 & I & 5 & I & 一 \\
\hline 3.03 & 一 & 8 & 7 & - \\
\hline 3.11 & - & 5 & 6 & 一 \\
\hline $3 \cdot 30$ & I & 4 & 8 & - \\
\hline $3 \cdot 37$ & - & 5 & II & - \\
\hline 3.49 & - & 3 & 6 & - \\
\hline 3.53 & - & 7 & I9 & I \\
\hline 3.69 & - & I & I4 & - \\
\hline $3.7 \mathrm{I}$ & - & I & 6 & - \\
\hline $3 \cdot 76$ & - & 3 & 15 & I \\
\hline $3.9 \mathrm{I}$ & - & I & 6 & I \\
\hline 4.05 & - & I & I2 & 2 \\
\hline $4 \cdot 17$ & - & - & 3 & - \\
\hline $4 \cdot 20$ & - & - & I & I \\
\hline - & - & - & - & - \\
\hline $4: 49$ & - & - & 3 & 一 \\
\hline 64 & - & - & I & - \\
\hline & - & - & - & - \\
\hline & 3 & 55 & II9 & 6 \\
\hline
\end{tabular}


comparatively very high. Among the forty third-year specimens, the first year's growth of seventeen individuals was higher than the second year's growth, and the mean of the first year's growth is slightly lower than the second year's growth. In those males breeding in the fourth year the rate of twelve specimens was highest in the first year, of eighty highest in the second year, and in only fifteen highest in the third year. The mean of the first year's

Table VII. Actual Numbers and Percentages of Mature Males Above i2O mm., Obtained in Different Months Throughout one Complete YEAR

$\begin{array}{lcc}\text { Month } & \begin{array}{c}\text { No. of } \\ \text { mature } \\ \text { males }\end{array} & \begin{array}{c}\text { Percentage of } \\ \text { mature } \\ \text { males }\end{array} \\ \text { Apr. 1949 } & 42 & 62 \cdot 7 \\ \text { May 1949 } & 90 & 68 \cdot 7 \\ \text { June I949 } & 55 & 25 \cdot 3 \\ \text { July 1949 } & 34 & \text { I5.0 } \\ \text { Aug. 1949 } & \text { I0 } & \text { 11.8 } \\ \text { Sept. 1949 } & \text { II } & 9 \cdot 8 \\ \text { Oct. 1949 } & 4 & 4 \cdot 4 \\ \text { Nov. 1949 } & \text { I6 } & 9 \cdot 2 \\ \text { Dec. 1949 } & 64 & 53 \cdot 3 \\ \text { Jan. 1950 } & 28 & 52 \cdot 8 \\ \text { Feb. 1950 } & 39 & 60 \cdot 9 \\ \text { Mar. I950 } & 89 & 78 \cdot \text { I } \\ \text { Total } & 482 & -\end{array}$

Table Vili. Comparison of the Rate of Growth in the Males Which BreEd at the Three DifFerent Ages

\begin{tabular}{|c|c|c|c|c|c|c|}
\hline \multirow{3}{*}{$\begin{array}{l}\text { Males } \\
\text { breeding in } \\
\text { 3rd year }\end{array}$} & \multirow[b]{2}{*}{ No. } & \multirow{2}{*}{$\begin{array}{c}\text { Successive } \\
\text { rings }\end{array}$} & \multicolumn{2}{|c|}{$\begin{array}{l}\text { Lengths of } \\
\text { successive rings on } \\
\text { radial (mm.) }\end{array}$} & \multirow{2}{*}{$\begin{array}{l}\text { Calculated } \\
\text { annual } \\
\text { increment } \\
\text { of body } \\
\text { length } \\
\text { (mm.) }\end{array}$} & \multirow{2}{*}{$\begin{array}{l}\text { Calculated } \\
\text { mean } \\
\text { body length } \\
\text { at the end } \\
\text { of successive } \\
\text { rings (mm.) }\end{array}$} \\
\hline & & & mean & $\sigma$ & & \\
\hline & 43 & $\begin{array}{l}\text { Ist ring } \\
\text { 2nd ring }\end{array}$ & $\begin{array}{l}\text { I. } 47 \\
\text { I. } 50\end{array}$ & $\begin{array}{l}0.32 \\
0.27\end{array}$ & $\begin{array}{l}71 \cdot 9 \\
73 \cdot 4\end{array}$ & $\begin{array}{r}7 \mathrm{I} \cdot 9 \\
145 \cdot 3\end{array}$ \\
\hline $4^{\text {th }}$ year & 107 & $\begin{array}{l}\text { Ist ring } \\
\text { 2nd ring } \\
\text { 3rd ring }\end{array}$ & $\begin{array}{l}0.95 \\
1 \cdot 48 \\
1 \cdot 16\end{array}$ & $\begin{array}{l}0.25 \\
0.25 \\
0.28\end{array}$ & $\begin{array}{l}45 \cdot 7 \\
72 \cdot 4 \\
56 \cdot 3\end{array}$ & $\begin{array}{r}45 \cdot 7 \\
\text { II } 8 \cdot 1 \\
\text { I } 74 \cdot 4\end{array}$ \\
\hline 5 th year & 6 & $\begin{array}{l}\text { Ist ring } \\
\text { 2nd ring } \\
\text { 3rd ring } \\
\text { 4th ring }\end{array}$ & $\begin{array}{l}0.69 \\
1.08 \\
\mathrm{I} \cdot 19 \\
0.81\end{array}$ & $\begin{array}{l}0.17 \\
0.21 \\
0.25 \\
0.20\end{array}$ & $\begin{array}{l}32 \cdot 7 \\
52 \cdot 3 \\
57 \cdot 8 \\
38 \cdot 7\end{array}$ & $\begin{array}{r}32 \cdot 7 \\
85 \cdot 0 \\
142 \cdot 8 \\
181 \cdot 5\end{array}$ \\
\hline
\end{tabular}

growth was much smaller than in the other 2 years. Among the males breeding in the fifth year, two specimens showed their highest growth rate in the first year, three in the second year, and one has its third year's growth almost equal to that of the fourth year. As in their growth rates these three groups of breeding males are so different from each other, they must be very different from each other physiologically.

The presence of large immature males with three complete winter rings on 
the radial, and of a considerable number of immature males, further proves that the fifth-year male breeders are neither the same third-year breeders of 2 years earlier nor the fourth-year breeders of I year earlier. Similarly, the fourthyear breeders are not the third-year breeders of I year before.

The length-weight relation and the secondary sexual characters also show that the males of C. lyra breed only once in their life. Besides the well-known example of Anguilla, which breeds only once during life, Callionymus lyra provides one of the most interesting illustrations of natural death among the large fishes.

\section{SUMMARY}

Both the otoliths and the second radials of the pectoral girdle can be used for age determination in Callionymus lyra L. Since the latter are far more satisfactory than the former, the second radial was selected for this work and the otolith was used only to check age reading. The radial is here used for the first time for age determination in fish.

The male may live up to 5 years (with four complete ossified winter rings), while the females may live 2 years longer (with six complete ossified winter rings). However, the males grow much quicker and to a larger size (239 $\mathrm{mm}$. long) than the females ( $185 \mathrm{~mm}$.).

The age of the spawning males falls into three age groups: (A) those that breed in the third year having two complete winter rings; (B) those that breed in the fourth year having three; (c) those that breed in the fifth year having four.

An analysis of the rates of growth of the spent males of three age groups shows that the rate of growth is highest in the third-year breeders, and is lowest in the fifth-year breeders.

Evidence has been given showing that the males of $C$. lyra breed only once and subsequently die. Breeding of the females has not been worked out.

\section{REFERENCES}

Corbin, P. G., I948. On the seasonal abundance of young fish. IX. The year I947. Fourn. Mar. Biol. Assoc., Vol. 27, pp. 718-22.

Couch, J., I863. A History of the Fishes of the British Islands, Vol. 2. London.

Cunningham, J. T., I891. The eggs and larva of Callionymus lyra. Fourn. Mar. Biol. Assoc., Vol. 2, pp. 89-90.

Desbrosses, P., 1949. Dimorphisme sexuel chez quelques Téléostéens de la côte Atlantique française. Fourn. Cons. Int. Explor. Mer, Vol. 16, pp. 63-73.

Donovan, E., I808. The Natural History of British Fishes, Vol. I. London. [Plate IX.]

Duncker, G., Ehrenbaum, E., Kyle, H. M., Mohr, E. W. \& Schnakenbeck, W., 1929. Die Fische der Nord- und Ostsee. Leipzig.

Ehrenbaum, E., 1905-09. Eier und Larven von Fischen. Nordisches Plankton, Lief. IV (I905), Teil I; Lief. x (I909), Teil II. 4I3 pp.

FAGE, L., I918. Shore-fishes. Rep. Danish Oceanogr. Exped. Medit., No. 4, Vol. II (Biology), A. 3, pp. I-I54.

Ford, E., I937. Vertebral variation in teleostean fishes. Fourn. Mar. Biol. Assoc., Vol. 22, pp. I-6o. 
FowleR, H. W., 1936. The marine fishes of West Africa, based on the collection of the American Museum Congo Expedition, 1909-15. Bull. Amer. Mus. Nat. Hist., Vol. 70, pp. I-I493.

Frost, G. A., 1928. A comparative study of the otoliths of the neopterygian fishes. Ann. Mag. Nat. Hist., Ser. Io, Vol. I, pp. 45I-6.

Gallien, L., I934. Croissance harmonique et dysharmonique des nageoires chez Callionymus lyra L. Bull. Soc. Zool. France, T. 59, pp. I35-40.

GüNTHER, A., I86I. Catalogue of the Acanthopterygian Fishes in the Collection of the British Museum, Vol. 3. London.

Holt, E. W. L., I897. Notes on the reproduction of teleostean fishes in the southwestern district. Fourn. Mar. Biol. Assoc., Vol. 5, pp. 107-55.

- I898. On the breeding of the Dragonet (Callionymus lyra) in the Marine Biological Association's Aquarium at Plymouth; with a preliminary account of the elements, and some remarks on the significance of the sexual dimorphism. Proc. Zool. Soc. London, I898, Vol. I, pp. 28I-3I5.

Holt, E. W. L. \& ScotT, S. D., I898. A record of the teleostean eggs and larvae observed at Plymouth in 1897. Fourn. Mar. Biol. Assoc., Vol. 5, pp. I56-7I.

KimURA, S. \& TAO, Y. S., I937. Notes on the nuptial coloration and pearl organs in Chinese fresh-water fishes. Bull. Shanghai Sci. Inst. Vol. 6, pp. 277-3I8.

Letaconnoux, R., I949. Note sur les caractères sexuels secondaires du Callionymus lyra. Fourn. Cons. Int. Explor. Mer, Vol. I6, pp. 59-62.

Menon, M. D., I950. Bionomics of the poor-cod (Gadus minutus L.) in the Plymouth area. Fourn. Mar. Biol. Assoc., Vol. 29, pp. I85-239.

Mielck, W., 1925. Heringslarven, Eier und Larven anderer Fische und Nahrung der Larven in dem Westlichen Nordsee im Oktober 1922. Ber. Deutsch. Wiss. Komm. Meeresforsch., N.F., Bd. I, pp. 209-46.

M'Intosh, W. C., I885. Notes from the St Andrews Marine Laboratory (under the Fishery Board for Scotland). Ann. Nat. Hist., Ser. 5, Vol. 16, pp. 480-7.

M'Intosh, W. C. \& Prince, E. E., I889. On the development and life histories of the teleostean food- and other fishes. Trans. Roy. Soc. Edinb., Vol. 35, pp. 665-946.

Norman, J. R., I947. A History of Fishes, 3rd ed. London.

Poll, M., I949. Résultats scientifiques des croisières de Navire-École belge 'Mercator'. IV. Poissons. Mem. Inst. Roy. Sci. Nat. Belg., Ser. II, Fasc. 33, pp. 173-269.

Russell, F. S., I930-47. The seasonal abundance and distribution of the pelagic young of teleostean fishes caught in the ring-trawl in offshore waters in the Plymouth area. I-VIII. Fourn. Mar. Biol. Assoc., Vols. I6, pp. 707-22; 20, pp. I47-79 and pp. 595-604; 2I, pp. 679-86; 22, pp. 493-500; 23, pp. 38I-6; 24 , pp. $265-70 ; 26$, pp. $605-8$.

Smitt, F. A., I892-95. A History of Scandinavian Fishes, Parts I and II. 2nd ed. Stockholm.

YARRELL, W., 1859. A History of British Fishes, Vol. 2, 3rd ed. London.

\section{EXPLANATION OF PLATE I}

PLATE I. Second radials of Callionymus lyra

Fig. I. Female aged I+, length $69 \mathrm{~mm}$., April 1949.

Fig. 2. Mature male aged 2+, length $168 \mathrm{~mm}$., March 1949 .

Fig. 3. Mature male aged $3+$, length $198 \mathrm{~mm}$.

Fig. 4. Female aged $4+$, length $185 \mathrm{~mm}$., May 1949.

Fig. 5. Male aged $5+$, length $172 \mathrm{~mm}$., Oct. I 949.

Fig. 6. Female aged 6+, length 179 mm., Nov. I948. 

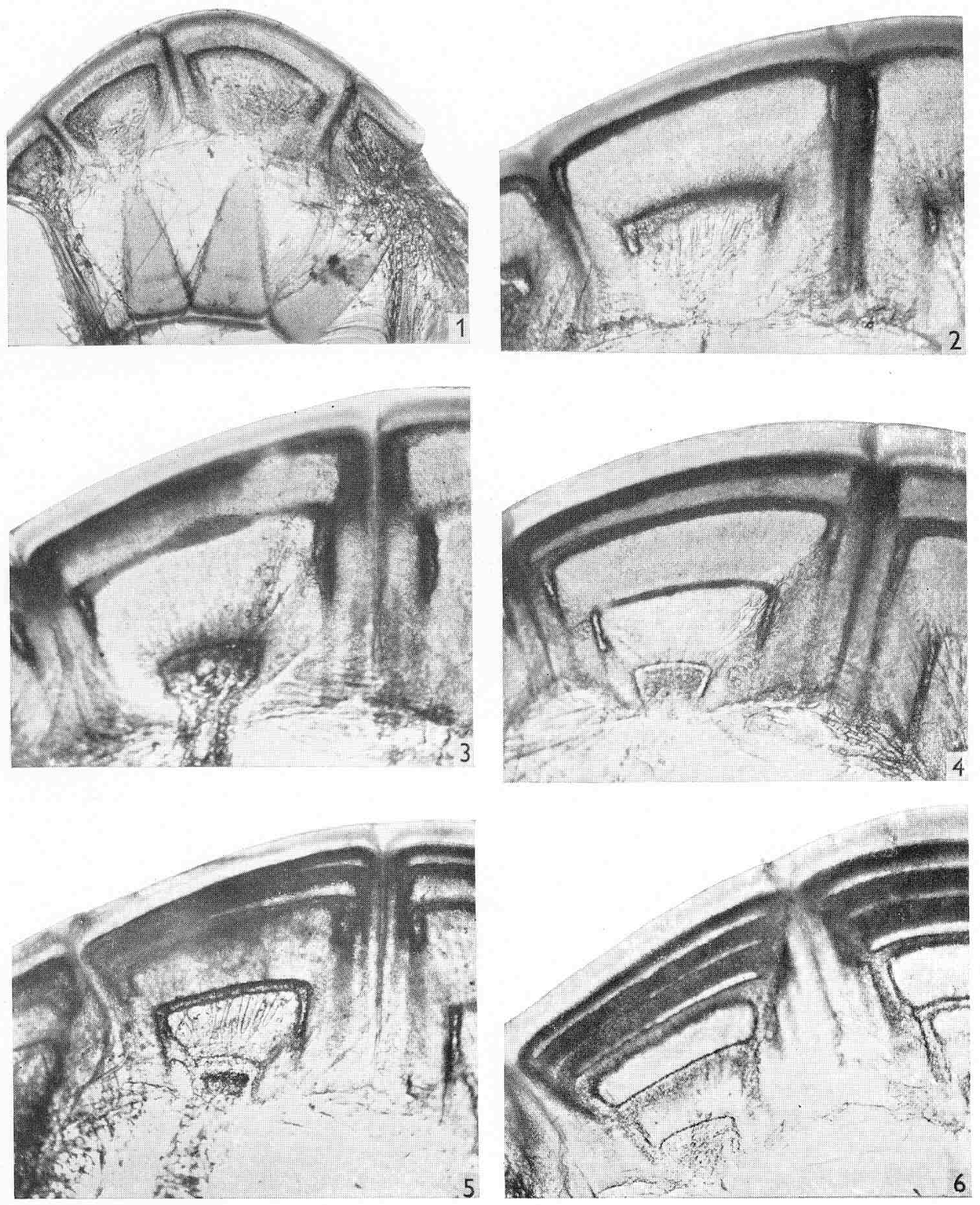

Figs. I-6. 